Jurnal Kajian Gender dan Anak

Vol. 02 No. 2 Desember 2018

e-ISSN : 2549-6352, p-ISSN: 2549-6344

Web: jurnal.iain-padangsidimpuan.ac.id/index.php/JurnalGender

\title{
KEHARMONISAN KELUARGA WANITA KARIER DI KELURAHAN PADANGMATINGGI LESTARI
}

\author{
ASNAH \\ IAIN Padangsidimpuan
}

\begin{abstract}
Abstrak
Terjunnya wanita dalam dunia kerja memunculkan permasalahan baru, dimana wanita bekerja terutama ibu rumah tangga akan tersita waktunya untuk keluarga, hal ini menimbulkan permasalahan terhadap keharmonisan keluarga. Atas dasar permasalahan di atas, penelitian ini berkeinginan mengetahui bagaimana pemberdayaan wanita, mengapa wanita ingin bekerja, apakah tidak menjadi masalah terhadap keharmonisan keluarga keluarga mereka. Penelitian ini dilaksanakan di kelurahan Padangmatinggi Lestari dengan pendekatan kualitatif. Instrumen yang digunakan adalah lembar observasi dan wawancara, dimana subjek yang dijadikan informan adalah ibu-ibu yang berprofesi sebagai guru, bidan dan karyawati. Kemudian dinalisis dengan menggunakan analisis longwe. Berdasarkan data yang diperoleh dapat diambil kesimpulan bahwa pemberdayaan wanita karier dilihat dari kesejahteraan sudah dapat meningkatkan kesejahteraan keluarga, namun kesadarannya terhadap peran gender dan aksesnya masih terbatas demikian juga dengan kekuasaannya dalam hal mengambil keputusan masih didominasi oleh laki-laki (suami). Hal ini sejalan dengan faktor pendorong wanita untuk bekerja, umumnya untuk meningkatkan ekonomi keluarga, bukan karena kesadaran akan hak-haknya sebagai wanita. Berdasarkan kriteria yang dicantumkan dalam kajian teori dan hasil wawancara dengan informan dapat dikatakan bahwa keluarga wanita karier
\end{abstract}

\section{A. PENDAHULUAN}

1. Latar Belakang Masalah di kelurahan Padangmatinggi Lestari dikategorikan keluarga sejahtera.

\section{Abstract}

The plunge of women in the world of work creates new problems, where working-women escpecially housewives will be time-consuming for the family, this creates problems with family harmony. On the basis of the above problems, this study wants to know how to empower women, why women want to work, is not a problem for the harmony of their family. This research was carried out in the Padangmatinggi Lestari village with a qualitative approach. The instruments used were observation sheets and interviews, where the subjects used as informants were mothers who worked as teachers, midwives and employees. Then analyze it using longwe analysis. Based on the data obtained it can be concluded that the empowerment of career women seen from welfare has been able to improve family welfare, but its awareness of gender roles and access is still limited as well as its power in making decisions still dominated by men (husbands). This is in line with the motivating factors for women to work, generally to improve the family economy, not because of awareness of their rights as women. Based on the criteria included in the theoretical study and the results of interviews with informants, it can be said that the families of career women in the Padangmatinggi Lestari village are categorized as prosperous families. 


\section{Jurnal Kajian Gender dan Anak}

Vol. 02 No. 2 Desember 2018

Pusat Studi Gender dan Anak

IAIN Padangsidimpuan

Isu perempuan menjadi perhatian dunia bahkan muncul pada agenda PBB dengan fokus utama meningkatkan peran perempuan dalam pembangunan. Strategi peningkatan peran perempuan dalam pembangunan ini didasarkan pada asumsi bahwa permasalahan kaum perempuan berakar dari rendahnya kualitas sumber daya kaum perempuan itu sendiri, hal tersebut mengakibatkan mereka tidak mampu bersaing dengan kaum laki-laki. Baik dalam masyarakat maupun dalam pembangunan.

Sebagai respon terhadap agenda PBB tersebut, pemerintah Indonesia memasukkan kebijakan perempuan dengan kebijakan "peran ganda perempuan". Kebijakan ini berdasarkan asumsi bahwa selama ini kaum perempuan hanya berperan sebagai ibu dan istri, dianggap tidak mempunyai peranan atau tidak memberikan kontribusi dalam pembangunan. Dengan kata lain perempuan dianggap sebagai beban, dan oleh karena itu harus diubah menjadi aset. Berdasarkan asumsi inilah, kaum perempuan didorong untuk berpartisipasi aktif di sektor publik dengan tetap menjalankan fungsinya sebagai ibu dan istri. ${ }^{1}$

Pada perkembangan masyarakat dewasa ini, peran wanita telah berubah sedemikian luas, dari sekadar mengurus rumah tangga sampai menjalankan suatu propesi lainnya, atau sering disebut dengan peran ganda wanita bekerja di luar rumah dengan berbagai motivasi mulai dari aktualisasi diri sampai tujuan memperoleh upah atau imbalan.

Salah satu faktor yang mengangkat kehormatan wanita adalah kemampuan untuk berdiri sendiri dalam memenuhi kebutuhan hidupnya tanpa harus menjadi beban orang lain dan kehormatan tersebut tidak akan dicapai kecuali dengan bekerja. ${ }^{2}$

\footnotetext{
1 Rahayu Surtiat, Perempuan Indonesia dalam Masyarakat yang Tengah Berubah (Jakarta: PKSW UI, 2000), hlm. 31.

${ }^{2}$ La Rose, Dunia Wanita (Jakarta: Pustaka, 2005), hlm. 93.
} 


\section{Keharmonisan Keluarga Wanita Karir .... \\ Asnah \\ asnah@iain-padangsidimpuan.ac.id}

Dengan adanya wanita bekerja di luar rumah maka berarti menyita waktunya untuk mengurus rumah tangga karena banyak menggunakan waktu melaksanakan pekerjaan, misalnya wanita bekerja di pabrikpabrik, wanita yang bekerja di pertokoan, di pom bensin, di pusat-pusat pasar, di perindustrian, di lembaga pendidikan, instansi pemerintahan dan lain sebagainya.

Sementara tugas wanita itu sendiri di dalam rumah tidaklah kalah pentingnya, karena peran wanita di dalam rumah sangat menentukan untuk membentuk keluarga yang harmonis, dimana dia berperan sebagai istri dan ibu dari anak-anaknya. Jane Carry Peck mengungkapkan:

Suami (ayah) berada pada puncak piramida, dipandang dan menjadi tempat bergantung anggota keluarga yang lain serta menjadi pembuat keputusan utama, walaupun istri (ibu) jauh lebih aktif dalam kehidupan sehari-hari di dalam rumah, khususnya dengan anak-anak. Bagi suami, keluarga hanya merupakan sebagian dari hidup mereka. Dalam keluarga istri memberikan seluruh dirinya sedangkan suami hanya memberikan sebagian dari dirinya. ${ }^{3}$

Berdasarkan pendapat di atas, wanita dalam keluarga mempunyai porsi yang sangat besar untuk kelangsungan keluarga menuju keluarga yang bahagia, sejahtera dan pada akhirnya membentuk keluarga yang harmonis.

Untuk dapat mewujudkan keluarga yang harmonis perlu upaya yang maksimal dari anggota keluarga, dikarenakan keluarga harmonis ditentukan oleh banyak faktor. Peranan wanita sebagai ibu rumah tangga sangatlah menentukan dalam membentuk keluarga yang harmonis, dimana para wanita di dalam rumah tangga berperan sebagai ibu dan sebagai istri, sehingga keluarga merupakan pusat kehidupan.

\footnotetext{
3 Jane Carry Peck, Wanita dalam Keluarga (Yogyakarta: Kartisius, 2002), hlm. 59.
} 
Sementara pada era globalisasi ini banyak para ibu rumah tangga yang bekerja di luar rumah, berarti sebagian tenaga dan waktunya akan tersita untuk mengerjakan pekerjaannya di luar rumah, kadangkala harus bekerja di waktu malam hari bahkan harus pergi meninggalkan keluarga untuk urusan pekerjaan.

Berdasarkan data penduduk kelurahan Padangmatinggi Lestari ada lebih kurang 605 KK, 60\% dari keluarga tersebut suami istri bekerja di berbagai sektor baik di instansi pemerintah, lembaga pendidikan, perdagangan dan sebagainya. Ketika wanita terlibat aktif dalam dunia kerja, tentu akan berimplikasi terhadap segala aspek kehidupan, baik kehidupan pribadi dan keluarga maupun kehidupan masyarakat sekitarnya.

Menurut pengamatan peneliti selama tinggal (sejak tahun 2003 2016) di lingkungan I kelurahan Padangmatinggi Lestari, kondisi keluarga di lingkungan ini alhamdulillah baik-baik saja dengan indikasi tidak sering terjadi keributan dikarenakan pertengkaran dalam rumah tangga, anak-anak juga tidak terlibat tindakan pelanggaran hukum atau terlibat masalah di masyarakat.

Walaupun keadaan keluarga kelihatan aman tanpa ada keributan, tidak menutup kemungkinan adanya ketidakharmonisan dalam rumahtangga, ketika dilihat dari adanya saling menghargai antara anggotanya, saling bertanggungjawab terhadap kesejahteraan keluarga melalui komunikasi yang terbuka, setiap anggota keluarga mendapat pengakuan atas peran dan atas haknya untuk mewujudkan diri. Asumsi ini, peneliti dasari dari sisi budaya Batak yang masih memegang prinsip patrilinial, dimana laki-laki/suami sebagai pemegang kekuasaan/keputusan dalam rumah tangga. Hal ini mengakibatkan berkurangnya hak wanita/istri baik yang bekerja maupun yang tidak bekerja, sehingga berakibat terhadap pembentukan keluarga yang harmonis. 


\section{Keharmonisan Keluarga Wanita Karir .... \\ Asnah \\ asnah@iain-padangsidimpuan.ac.id}

Berangkat dari asumsi tersebut peneliti mengajukan penelitian dengan permasalahan keharmonisan keluarga wanita karir di kelurahan Padangmatinggi Lestari.

2. Fokus Penelitian

Penelitian ini memfokuskan pada wanita yang bekerja sebagai guru, bidan dan karyawati baik di instansi pemerintah maupun swasta. Selanjutnya kondisi keharmonisan keluarga wanita karir ini dilihat dari adanya saling menghargai antara anggotanya, saling bertanggungjawab terhadap kesejahteraan keluarga melalui komunikasi yang terbuka, setiap anggota keluarga mendapat pengakuan atas peran dan atas haknya untuk mewujudkan diri.

3. Rumusan Masalah

Berdasarkan latar belakang di atas, maka yang menjadi permasalahan yang dikaji dalam penelitian ini adalah:

a. Bagaimana pemberdayaan wanita karier dilihat dari kesejahteraan, akses, kesadaran kritis, partisipasi dan kontrol/kuasa di Kelurahan Padangmatinggi Lestari?

b. Apa faktor pendorong wanita di Kelurahan Padangmatinggi Lestari bekerja?

c. Bagaimana kondisi keharmonisan keluarga wanita karier di Kelurahan Padangmatinggi Lestari?

4. Tujuan Penelitian

Penelitian ini bertujuan untuk:

a. Mengetahui pemberdayaan wanita karier dilihat dari kesejahteraan, akses, kesadaran kritis, partisipasi dan kontrol/kuasa di Kelurahan Padangmatinggi Lestari.

b. Menemukan faktor pendorong wanita bekerja di Kelurahan Padangmatinggi Lestari.

c. Menganalisis keharmonisan keluarga wanita karier di Kelurahan Padangmatinggi Lestari. 


\section{Jurnal Kajian Gender dan Anak}

Vol. 02 No. 2 Desember 2018

Pusat Studi Gender dan Anak

IAIN Padangsidimpuan

5. Manfaat Penelitian

Penelitian ini diharapkan dapat memberikan manfaat antara lain:

a. Manfaat Teoritis

Sebagai tambahan khasanah pengembangan ilmu, terutama dalam pemberdayaan wanita di berbagai bidang.

b. Manfaat Praktis

1) Sebagai tambahan bahan kajian bagi lembaga yang bekerja di bidang gender dan anak, sehingga dapat memperluas ilmu pengetahuan, khususnya dalam mengupayakan kesetaraan gender.

2) Bagi pekerja wanita sebagai bahan pertimbangan dan masukan untuk kesuksesan dalam dunia kerja dan juga dalam keluarga.

\section{B. KAJIAN TEORI}

1. Konsep Wanita Karier

Menurut Kamus Besar Bahasa Indonesia, karier berarti 1) Perkembangan dan kemajuan dalam kehidupan, pekerjaan dan jabatan 2) Pekerjaan yang memberikan harapan untuk maju. ${ }^{4}$ Karier dapat juga diartikan sebagai urut-urutan status yang diiringi oleh peningkatan prestasi seseorang. ${ }^{5}$

Menurut A. Hafiz Anshary A.Z dalam Irwan Abdulah, wanita karier adalah wanita-wanita yang menekuni profesi atau pekerjaannya dan melakukan aktivitas untuk meningkatkan hasil dan prestasinya. Wanita seperti ini tidak seperti wanita di zaman Siti Nurbaya yang hanya mendekam di dalam rumah merenungi nasib, terkungkung oleh tembok, pagar adat dan tradisi. Sementara wanita karier adalah wanita

\footnotetext{
${ }^{4}$ Tim Penyusun Kamus Pusat Bahasa, Kamus Besar Bahasa Indonesia (Jakarta: Balai Pustaka, 2005), hlm. 508.

${ }^{5}$ La Rose, Op.Cit., hlm. 70.
} 


\section{Keharmonisan Keluarga Wanita Karir .... \\ Asnah \\ asnah@iain-padangsidimpuan.ac.id}

sibuk, wanita kerja yang waktunya di luar rumah terkadang lebih banyak banyak dari pada di rumah. ${ }^{6}$

Dengan demikian wanita karier dapat diartikan dengan wanita yang berkecimpung dalam kegiatan profesi (usaha, perkantoran, guru, dan sebagainya).

\section{Faktor Pendorong Wanita Bekerja}

Beberapa faktor yang melandasi wanita untuk bekerja di luar rumah di antaranya adalah:

a. Kebutuhan finansial

b. Kebutuhan sosial-rasional

c. Kebutuhan aktualisasi diri. ${ }^{7}$

Tidak sedikit wanita yang mampu mengerjakan pekerjaan pria pada umumnya. Peran wanita tersebut bukan tanpa alasan, banyak alasan yang mungkin menjadi dorongan tersendiri bagi wanita untuk memanfaatkan emansipasi yang telah didapatkannya.

\section{Pemberdayaan Wanita}

Dalam pemberdayaan wanita, Widaningrum mengemukakan lima kriteria analisis yang meliputi; kesejahteraan, akses, kesadaran kritis, partisipasi dan kontrol. ${ }^{8}$ Pada tingkat kesejahteraan, pemberdayaan tidak dapat terjadi dengan sendirinya, melainkan harus dikaitkan dengan peningkatan akses terhadap sumber daya yang merupakan dimensi tingkat kedua.

Dalam banyak komunitas, perempuan diberi tanggung jawab melaksanakan hampir semua pekerjaan domestik sehingga tidak mempunyai waktu cukup untuk mengurusi dan meningkatkan kemampuan dirinya. Kurangnya akses perempuan bukan saja

\footnotetext{
${ }^{6}$ Irwan Abdullah, Problematika Hukum Islam Kontemporer (Jakarta: Pustaka Firdaus, 2002), hlm. 12.

7 Fatmawati Harun, Faktor-faktor yang Mempengaruhi Perempuan Bekerja dan Kesejahteraan Keluarga (Yogyakarta: Gadjah Mada University Press, 2010), hlm. 68.

${ }^{8}$ Widaningrum, Metode Moser dan Aplikasinya (Yogyakarta: Pusat Studi Wanita UGM, 1998), hlm. 12.
} 


\section{Jurnal Kajian Gender dan Anak}

Vol. 02 No. 2 Desember 2018

Pusat Studi Gender dan Anak

IAIN Padangsidimpuan

merupakan isu gender tetapi juga akibat dari diskriminasi gender. Oleh karena itu akar penyebab kesenjangan akses atas sumber daya adalah diskriminasi sistemik yang harus diatasi melalui penyadaran. ${ }^{9}$

Pemberdayaan ditingkat kesadaran kritis berarti menumbuhkan sikap kritis dan penolakan terhadap cara pandang yang salah terhadap perempuan. Keyakinan bahwa kesetaraan gender adalah bagian dari tujuan perubahan merupakan inti dari kesadaran gender dan merupakan elemen idiologis dalam proses pemberdayaan. Demikian pula halnya dengan partisipasi aktif perempuan adalah adanya peran serta yang setara antara laki-laki dan perempuan. Dimensi terakhir dalam pemberdayaan perempuan adalah kuasa/kontrol. Kesetaraan dalam kuasa berarti adanya kuasa yang seimbang antara laki-laki dan perempuan, satu tidak mendominasi atau berada dalam posisi dominan atas yang lainnya. Artinya perempuan mempunyai kekuasaan sebagaimana juga laki-laki untuk mengubah kondisi posisi, masa depan diri dan komunitasnya. ${ }^{10}$ Pemberdayaan wanita secara tepat akan meningkatkan produktivitas dan dapat meningkatkan kesejahteraan dan keharmonisan keluarga secara maksimal. ${ }^{11}$

Dimensi kesejahteraan merupakan tingkat kesejahteraan material yang diukur dari tercukupinya kebutuhan dasar seperti makanan, penghasilan, perumahan dan kesehatan. Apakah dengan bekerja dapat memenuhi kesejahteraan keluarga.

Selanjutnya memahami bagaimana akses tenaga kerja wanita, apakah mereka memiliki kesempatan untuk mengembangkan diri serta sejauhmana mereka memberikan manfaat bagi keluarga. Apakah suami mendukung kesempatan akses tersebut. Apakah wanita karir tersebut memiliki kesadaran kritis terhadap kesetaraan gender, apakah ada

\footnotetext{
${ }^{9}$ Purwandari, Perempuan dan Pemberdayaan (Jakarta: Oborr, 2007), hlm. 63.

${ }^{10}$ Ibid., hlm. 63-64.

${ }^{11}$ Purwandari, Op.Cit., hlm.51.
} 


\section{Keharmonisan Keluarga Wanita Karir .... \\ Asnah \\ asnah@iain-padangsidimpuan.ac.id}

anggapan bahwa posisi wanita lebih rendah dari laki-laki. Apakah anggapan tersebut merupakan pengaturan alamiah atau hasil diskriminasi dari tatanan sosial yang berlaku.

Sementara partisipasi aktif wanita karir dilihat keterlibatan dan keikutsertaan wanita karir dalam berbagai kegiatan baik di tempat bekerja, dalam keluarga juga masyarakat. Apakah wanita ikut serta dalam proses perencanaan, penentuan kebijakan dan pengambilan keputusan dalam keluarga. Kontrol berarti wanita mempunyai kekuasaan untuk mengambil keputusan, mengubah posisi dan sebagainya.

Dengan adanya kesejahteraan wanita karier tentu bertambah penghasilan keluarga, begitu juga dengan adanya kesempatan untuk mengurusi dan mengembangkan dirinya maka akan menambah pengetahuan, memperluas wawasannya. Selanjutnya kesadaran kritis, partisipasi dan adanya hak atau kuasa dalam mengambil keputusan, maka wanita merasa dihargai, diterima aspirasi, kepentingan dan peranannya baik di tempat kerja maupun dalam keluarga.

\section{Konsekuensi Wanita Bekerja}

Terjunnya wanita dalam dunia kerja, banyak membawa pengaruh terhadap segala aspek kehidupan, baik kehidupan pribadi dan keluarga maupun kehidupan masyarakat sekitarnya.

Apabila wanita bekerja, maka tugasnya menjadi lebih berat, disamping bekerja, ia juga harus mengurus rumah tangga seperti melayani suami, mendidik anak, dan sebagainya. Hal ini tidak jarang sangat rentan menimbulkan masalah, karena seorang wanita sering dipersalahkan ketika anak-anak mereka prestasi belajarnya menurun atau merasa kurang diperhatikan yang berdampak anak kurang betah tinggal di rumah, dan tidak jarang anak-anak tersebut melakukan 


\section{Jurnal Kajian Gender dan Anak}

Vol. 02 No. 2 Desember 2018

Pusat Studi Gender dan Anak

IAIN Padangsidimpuan

perbuatan-perbuatan negatif yang bertentangan dengan norma agama dan sosial. ${ }^{12}$

Salah satu kodrat yang dimiliki wanita adalah melahirkan. ${ }^{13}$ Menjadi ibu adalah sebuah kebahagiaan bagi seorang wanita. Namun, kadang, bagi seorang wanita karier, ini menjadi dilema. Sebab, kebutuhan mengejar karier dan memberikan perhatian pada anak adalah dua hal yang kadang sering tak bisa berjalan beriringan.

Banyak wanita yang memilih berkarir sekaligus tetap menjalankan peranannya sebagai ibu rumah tangga yang berusaha mencari penghasilan tambahan untuk membantu suami mencari nafkah untuk keluarga namun wanita itu tetap dapat meluangkan waktu untuk mengurusi suami dan anak-anak, tidak jarang hal seperti inilah yang lebih disukai para suami, selain mendapatkan penghasilan tambahan juga sebagai isteri tetap dapat melayani semua kebutuhan suami dan anak-anak. Sebagaimana dikatakan Brunetta, jika kaum wanita bekerja di luar rumah dan mereka itu berkeluarga, maka mereka masih diharapkan mempertahankan citra wanita rumah tangga sepenuhnya. ${ }^{14}$

\section{Konsep Keluarga Harmonis}

Menurut Mahfudli Sahli keluarga harmonis adalah suami istri yang hidup di dalam ketenangan lahir batin karena merasa cukup dan puas atas segala sesuatu yang ada dan yang telah dicapai dalam melaksanakan tugas kerumahtanggaan yang menyangkut bidang nafkah, seksual, pergaulan antara anggota keluarga dan pergaulan masyarakat. 15

12 Abdullah A. Jawas, Dilema Wanita Karir: Menuju Keluarga Sakinah (Yogyakarta: Ababil, 1996), hlm. 36.

13 Nasruddin Umar, Kodrat Perempuan dalam Islam (Jakarta: Fikahati Aneska, 2000), hlm. 54.

${ }^{14}$ Brunetta R. Wolfman, Peran Kaum Wanita (Yogyakarta: Kanisius, 2008), hlm. 24.

15 Mahfudli Sahli, Menuju Rumah Tangga Harmonis (Pekalongan: Bahagian Batang, 2003), hlm. 148 


\section{Keharmonisan Keluarga Wanita Karir .... \\ Asnah \\ asnah@iain-padangsidimpuan.ac.id}

Selain itu keluarga harmonis merupakan suatu keluarga yang saling menghargai antara anggotanya, saling bertanggungjawab terhadap kesejahteraan keluarga melalui komunikasi yang terbuka, terjalin kasih sayang, saling pengertian, setiap anggota keluarga mendapat pengakuan atas perannya dan atas haknya untuk mewujudkan diri.16

Melihat beberapa definisi di atas, diketahui bahwa keluarga harmonis pada hakekatnya adalah keluarga yang serasi selaras dan seimbang, saling memberi dan menerima keadaan, kemampuan dan keterlibatan dalam sifat masing-masing. Keluarga harmonis sesungguhnya dapat mengacu pada suasana kehidupan yang baik. Dalam Islam keluarga sejahtera merupakan keluarga sakinah.

\section{METODOLOGI PENELITIAN}

1. Tempat dan Waktu Penelitian

Penelitian ini dilakukan di Kelurahan Padangmatinggi Lestari Kecamatan Padangsidimpuan Selatan Kota Padangsidimpuan. Kelurahan ini terdiri dari IV lingkungan, namun peneliti membatasi lingkungan penelitian hanya pada lingkungan I dan II, dengan pertimbangan subjek penelitian mayoritas berada di kedua lingkungan ini. Waktu yang dibutuhkan dalam penelitian lebih kurang 8 bulan, mulai bulan Maret sampai dengan November 2016.

\section{Jenis Penelitian}

Pendekatan yang dilakukan adalah pendekatan kualitatif. Sementara metode yang digunakan adalah metode deskriptif.

\section{Informan Penelitian}

Informan penelitian penelitian ini adalah ibu-ibu kelurahan Padangmatinggi Lestari di Lingkungan I dan II yang berprofesi sebagai guru, bidan, dan karyawati baik pada instansi pemerintah maupun

\footnotetext{
${ }^{16}$ Evelyn Suleeman ,"Hubungan-Hubungan dalam Keluarga", dalam T.O Ihromi, dkk (ed), Bunga Rampai Sosiologi Keluarga, Cet. I Jakarta: Yayasan Obor Indonesia, 1999), hlm. 56.
} 
swasta. Selain itu para suami dari wanita karier tersebut sesuai dengan data yang dibutuhkan.

\section{Metode Pengumpulan Data}

a. Observasi

Observasi ini digunakan untuk mengamati situasi, kegiatan atau aktivitas yang dilakukan, pola komunikasi yang dibangun dan waktu yang disediakan untuk keluarga oleh wanita karier serta berbagai perilaku lainnya dalam memainkan peranan yang terkait dengan keharmonisan keluarga di kelurahan Padangmatinggi Lestari, dimana peneliti merupakan salah satu warga di kelurahan tersebut.

b. Wawancara/Interview

Interview ini peneliti tujukan kepada wanita karier untuk mendapatkan gambaran tentang lima dimensi yang telah dijelaskan sebelumnya dan alasan-alasan mereka bekerja serta bagaimana mereka menyikapi peran ganda tersebut terkait dengan keharmonisan keluarga. Selain itu peneliti dengan didampingi oleh pembantu peneliti juga melakukan wawancara kepada suami yang istrinya bekerja sebagai wanita karier.

\section{Teknik Analisis Data}

Dalam menganalisis keharmonisan keluarga wanita karier, peneliti menggunakan teknik analisis gender. Dari analisis gender ini dikembangkan berbagai macam teknik analisis. Di antara teknik analisis dimaksud, yang peneliti gunakan adalah teknik analisis Longwe atau biasa disebut dengan Kriteria Pembangunan Perempuan, yaitu suatu teknik analisis yang dikembangkan sebagai metode pemberdayaan perempuan dengan lima kriteria analisis meliputi; kesejahteraan, akses, kesadaran kritis, partisipasi dan kontrol. ${ }^{17}$ 1996), hlm. 73 .

${ }^{17}$ M. Faqih, Analisis Gender dan Transformasi Sosial (Yogyakarta: Pustaka Pelajar, 


\section{Keharmonisan Keluarga Wanita Karir .... \\ Asnah \\ asnah@iain-padangsidimpuan.ac.id}

Lima dimensi pemberdayaan ini adalah kategori analitis yang bersifat dinamis, satu sama lain berhubungan secara sinergis, saling menguatkan dan melengkapi, serta mempunyai hubungan hirarkis. Di samping itu kelima dimensi tersebut juga merupakan tingkatan yang bergerak memutar seperti spiral, makin tinggi tingkat kesetaraan otomatis makin tinggi tingkat keberdayaan.

\section{DESKRIPSI HASIL PENELITIAN}

1. Kondisi wanita karier dilihat dari kesejahteraan, akses, kesadaran kritis, partisipasi dan kontrol/kuasa

\section{a. Kesejahteraan}

Berdasarkan hasil wawancara dengan ibu rumah tangga yang bekerja di Kelurahan Padangmatinggi Lestari, mereka mengemukakan bahwa sampai saat ini penghasilan yang mereka terima setiap bulan dapat memenuhi kesehatan dan memenuhi gizi anak-anak dan keluarga di rumah, bahkan bisa membeli pakaian dan perawatan di rumah sehat, ada juga yang pergi ke salon untuk perawatan wajah. ${ }^{18}$

Namun demikian masih ada yang menyatakan bahwa penghasilannya hanya dapat memenuhi kebutuhan pokok dan biaya pendidikan anak-anaknya, sementara suaminya hanya berprofesi sebagai tukang becak, petani bahkan ada yang tidak memiliki pekerjaan tetap. ${ }^{19}$

Dari 50 informan 85\% mengatakan bahwa dengan bekerjanya mereka maka kesejahteraan keluarga meningkat. Hal ini diperkuat dengan hasil observasi peneliti bahwa umumnya kondisi ekonomi

18 Dermawan Harahap, Imelda Rosa, Arnidawati, Gusti Nora dan Murtiati Mardia, guru, bidan dan karyawati baik PNS maupun swasta, wawancara di Padangmatinggi Lestari, hari Kamis 14 Juli 2016 pukul 14.35WIB.

${ }^{19}$ Elida Warni, Rosnah Ritonga, Lismasari, Masrina Ritonga, guru, dan karyawati PNS, wawancara di Padangmatinggi Lestari, hari Kamis 14 Juli 2016 pukul 17.15WIB. 
masyarakat Kelurahan Padangmatinggi Lestari dilihat dari keadaan rumah, fasilitas dan kenderaan yang dimiliki tergolong masyarakat menengah ke atas. ${ }^{20}$

\section{b. Akses terhadap Sumber Daya}

Untuk sementara ini kemampuan akses para ibu-ibu kelurahan Padangmatinggi Lestari yang bekerja terbatas pada pendidikan dan pelatihan (diklat), penataran-penataran saja, belum menjangkau akses yang lain seperti teknologi informasi, seperti diungkapkan beberapa informan: "Ketika kami ujian kompetensi guru, kami sangat kesulitan mengisi jawaban melalui komputer, karena kami nggak bisa mengoperasikan komputer, selama ini kami hanya minta tolong orang lain". Begitu juga dengan karyawati hanya beberapa orang saja yang mahir terhadap teknologi informasi, walaupun status mereka ada yang sebagai pejabat di instansi pemerintah. ${ }^{21}$

\section{c. Kesadaran Kritis}

Pemahaman informan mengenai kesetaraan gender masih rendah, umumnya kesadaran mereka terhadap kesetaraan gender masih pada batasan pekerjaan di luar rumah. Sementara peran wanita dalam rumah tangga masih bias gender. Seringkali ketidakikutsertaan wanita dalam pengembangan karier disebabkan oleh pengkotakan peran suami dan istri yang masih belum memahami kesetaraan gender sehingga pekerjaan domestik rumahtangga masih menjadi tanggung jawab perempuan sepenuhnya. Hal ini dapat dilihat dari pernyataan beberapa informan yang berpendapat bahwa kesetaraan antara istri dan suami terletak

\footnotetext{
${ }^{20}$ Observasi kondisi kesejahteraan ekonomi wanita karier di kelurahan Padangmatinggi Lestari, hari Minggu tgl 24 Juli 2016.

21 Nurhayati Nasution, Masriani Pulungan, Nurhalinda Siregar, Rosfitri Nasution wawancara hari Sabtu 6 Agustus 2016 Pukul 10.00 WIB.
} 


\section{Keharmonisan Keluarga Wanita Karir .... \\ Asnah \\ asnah@iain-padangsidimpuan.ac.id}

pada kesetaraan di bidang pekerjaan di luar rumah, sedangkan di dalam rumah tangga suami tetap menjadi pemimpin bagi istri. ${ }^{22}$

\section{d. Partisipasi}

Berdasarkan pada penelitian yang telah dilaksanakan terhadap lima puluh keluarga dengan latar belakang pendidikan dan pekerjaan yang berbeda, hasil mengenai partisipasi wanita karier dalam urusan publik dan domestik, menunjukkan bahwa keterlibatan wanita karier di kelurahan Padangmatinggi Lestari tidak hanya di bidang domestik, tetapi sudah terlibat di bidang pemerintahan, dan di bidang kemasyarakatan.

Berdasarkan hasil wawancara peneliti dengan beberapa informan diketahui bahwa partisipasi ibu-ibu (wanita karier) di kelurahan Padangmatinggi Lestari, selain berpartisipasi dalam kepentingan publik (sebagai guru, karyawati, bidan) mereka juga berpartisipasi dalam kegiatan dharma wanita atau PKK dan pengajian yang seluruh anggotanya notabene perempuan. ${ }^{23}$ Walaupun mereka bekerja namun masih sempat mengikuti berbagai pengajian yang dilaksanakan di masyarakat, seperti pengajian akbar, pengajian tafsir al-quran dan beberapa majlis taklim. ${ }^{24}$

\section{e. Kontrol/kuasa}

Sementara keterlibatan istri (wanita karier) untuk perencanaan, penentuan kebijakan dan pengambilan keputusan strategis dalam keluarga masih didominasi para lelaki (suami).

Salah satu kutipan wawancara peneliti kemukakan antara lain: "Dalam keluarga kami untuk masalah penting yang mengambil keputusan suami saya, walaupun kami memusyawarahkan masalah

\footnotetext{
${ }^{22}$ Jairun Harahap, Saharuddin, irjan, Dermina Sari, dan Masintan Lubis, wawancara hari Rabu 17 Agustus 2016 Pukul 14.00 WIB.

${ }^{23}$ Observasi terhadap partisipasi wanita karier dalam berbagai kegiatan, hari Senin dan Rabu tanggal 1, 3, 8 dan 10 Agustus 2016.

${ }^{24}$ Rohima Daulay, Delilah Harahap dan Masdewati Panggabean, wawancara hari Sabtu 27Agustus 2016 Pukul 11.00 WIB
} 
yang akan diputuskan itu, misalnya mau membeli tanah, membeli kenderaan atau merehab rumah". 25

\section{Faktor Pendorong Wanita Bekerja di Kelurahan Padangmatinggi Lestari}

Informan di dalam penelitian ini dikategorikan ke dalam dua bagian yaitu keluarga dengan istri bekerja sebelum menikah dan keluarga dengan istri bekerja setelah menikah. Istri yang bekerja sebelum menikah, secara tidak langsung suami mengijinkan istrinya bekerja, sehingga tidak ada kesepakatan antara suami-istri sebelum menikah mengenai karier istri setelah menikah.

Tujuan ibu-ibu di kelurahan Padangmatinggi Lestari bekerja umumnya untuk menambah pendapatan dan ekonomi keluarga. Hanya beberapa informan yang memiliki tujuan untuk memberdayakan dirinya sesuai dengan keilmuan dan pendidikan yang telah diterimanya. ${ }^{26}$

\section{Kondisi Keharmonisan Keluarga Wanita Karier di Kelurahan Padangmatinggi Lestari}

\section{a. Kesejahteraan dan Kedamaian}

Berdasarkan hasil observasi yang telah dilaksanakan terhadap lima puluh keluarga dengan latar belakang pendidikan dan pekerjaan yang berbeda, hasil mengenai kesejahteraan dan kedamaian keluarga hampir sama atau seragam. Umumnya para informan merasakan dari sisi ekonomi, kesejahteraan mereka menjadi lebih baik, dimana anakanak mereka bisa melanjutkan pendidikan ke tingkat yang lebih tinggi bahkan bisa sekolah sampai ke luar daerah/pulau. Dilihat dari sisi fasilitas rumah, kenderaan dan aset lain sudah mencukupi. ${ }^{27}$

\section{b. Saling Menghargai dan Pengertian}

\footnotetext{
${ }^{25}$ Enni Mazdalifah, wawancara hari Minggu 28 Agustus 2016 Pukul 9.00 WIB

26 Deni Afnita Siregar, Nurhayati Nasution, Rosfitri Nasution, dan Elfi Fitriani, wawancara hari Sabtu 3 September 2016 Pukul 17.15 WIB.

${ }^{27}$ Ovservasi kondisi kesejahteraan keluarga wanita karier di kelurahan Padangmatinggi Lestari pada hari Minggu tgl 24 Juli 2016.
} 


\section{Keharmonisan Keluarga Wanita Karir .... \\ Asnah \\ asnah@iain-padangsidimpuan.ac.id}

Umumnya suami informan sangat menghargai sumbangan yang diberikan istri mereka baik dari sisi ekonomi, mengurus rumah tangga, suami dan anak-anak. Ungkapan mereka hampir sama, yaitu; saya sangat bersyukur karena istri saya bisa membantu menambah masukan terhadap ekonomi keluarga kami, juga tetap menjalankan tugasnya sebagai ibu rumah tangga. ${ }^{28}$

Saling menghargai ini tidak hanya dari pihak suami, para istri (wanita karier) ini juga tetap menghargai suami mereka. Seperti ungkapan beberapa informan mengatakan walaupun saya punya penghasilan sendiri saya tetap mendiskusikan kepada suami jika ada yang ingin saya beli, kalau menurut suami belum perlu untuk dibeli maka saya mengurungkan niat saya. ${ }^{29}$

\section{c. Pengakuan akan peran dan tanggung jawab, hak dan kewajiban}

Pada dasarnya sikap saling menghargai muncul ketika masingmasing orang mengakui peran dan tanggung jawabnya, serta memenuhi hak dan kewajibannya. Demikian halnya dengan kondisi keluarga wanita karier di kelurahan Padangmatinggi Lestari. Mereka menyadari perannya masing-masing, baik sebagai suami dan juga peran istri selain sebagai ibu rumah tangga mereka juga diakui perannya sebagai wanita karier. Hal ini ditunjukkan dengan adanya keterlibatan suami mengurus rumah tangga karena mereka memahami kesibukan istri mereka.

Umumnya wanita karier di kelurahan Padangmatinggi Lestari tetap bekerja di sektor domestik dimana tanggungjawab pekerjaan rumah tangga masih didominasi istri. Walaupun tidak ada pembagian tugas yang tegas terhadap pekerjaan rumah tangga. Berbeda dengan

${ }^{28}$ P. Rambe, Sahaban Nasution, R.Pane, wawancara hari Minggu 11 September 2016 Pukul 8.25 WIB.

${ }^{29}$ Melly Rina Harahap, Rosmaida, Ratnawati dan Nurainun, wawancara hari Minggu 11 September 2016 Pukul 10.05 WIB. 


\section{Jurnal Kajian Gender dan Anak}

Vol. 02 No. 2 Desember 2018

Pusat Studi Gender dan Anak

IAIN Padangsidimpuan

keluarga yang memiliki pembantu rumah tangga, tugas mengerjakan pekerjaan rumah tangga tidak menjadi masalah.

Sebagaimana kutipan wawancara yang peneliti peroleh dari beberapa informan, yaitu:

Dalam rumah tangga kami, saya dan suami saya selalu mengedepankan kebersamaan. Apalagi saat saya mulai bekerja, otomatis waktu saya di rumah menjadi terbatas, terutama dalam mengurus rumah tangga dan anak. Itulah yang menyebabkan rasa tanggungjawab saya bertambah, sehingga saya tidak memperdulikan kelelahan saya untuk mengerjakan urusan rumah tangga. Jika suami saya punya kesempatan membantu pekerjaan rumah tangga saya merasa senang sekali, tapi saya tidak pernah memaksakannya. ${ }^{30}$

\section{d. Keterbukaan/komunikasi terbuka}

Keharmonisan keluarga juga dibangun dari adanya keterbukaan dan saling percaya di antara anggota keluarga tersebut. Menurut hasil wawancara peneliti dengan informan ada 2 tipe komunikasi yang dibangun dalam keluarga, tipe pertama, komunikasi terbuka, artinya dalam keluarga tersebut segala sesuatu dibicarakan bersama, baik pendapatan masing-masing (gaji), keinginan untuk membeli sesuatu, keinginan anak pergi bermain dan melanjutkan pendidikan serta pengeluaran keuangan untuk membantu keluarga. Tipe kedua, semi terbuka, maksudnya ada hal-hal tertentu yang tidak mereka bicarakan, misalnya pendapatan (gaji), masing-masing menyembunyikannya, berbicara pada hal-hal yang penting saja. Begitu pula dengan keinginan membantu keluarga, masing-masing membantu secara sembunyi-sembunyi, walaupun pada akhirnya mereka tahu. Hal ini kadangkala memicu pertengkaran. Dilihat dari jumlah informan yang diteliti, keluarga tipe ini jumlahnya tidak

\footnotetext{
${ }^{30}$ Melly Rina Harahap, wawancara hari Minggu 11 September 2016 Pukul 11.00 WIB.
} 


\section{Keharmonisan Keluarga Wanita Karir .... \\ Asnah \\ asnah@iain-padangsidimpuan.ac.id}

banyak hanya 12 keluarga (24\%). Umumnya keluarga tipe seperti ini pasangan suami istri yang asli berasal dari daerah Tapanuli Selatan. Sementara tipe keluarga pertama salah satu dari pasangan suami istri tersebut berasal dari luar Tapanuli Selatan, walaupun mereka tetap suku Batak Mandailing.

\section{e. Pendayagunaan waktu}

Berdasarkan penelitian yang dilaksanakan, pendayagunaan waktu wanita karier di kelurahan Padangmatinggi Lestari cukup efektif terutama bagi keluarga yang tidak memiliki asisten/pembatu rumah tangga. Hal ini dapat dilihat dari pembagian waktu mulai dari sebelum pergi bekerja para ibu telah menyiapkan makanan untuk sarapan dan makan siang bagi keluarganya sampai mereka kembali dari kantor mempersiapkan makan malam keluarga, membersihkan rumah, mengurus anak dan ketika malam hari mendampingi anak mengaji dan belajar. Walaupun mereka lelah seharian di kantor/mengajar tapi mereka tetap melaksanakan tugas mereka dengan ikhlas tanpa merasa ada beban. ${ }^{31}$

\section{f. Pengelolaan rumah}

Berdasarkan penelitian yang dilaksanakan, terhadap lima puluh keluarga di kelurahan Padangmatinggi Lestari, ada dua jenis pembagian kerja yang dapat dilihat dari pola kehidupan keluarga wanita karier di kelurahan ini yang istrinya bekerja di luar rumah. Pembagian kerja yang pertama adalah istri mempunyai tanggung jawab penuh dalam pekerjaan rumah. Jenis pembagian kerja yang kedua adanya kesadaran para suami untuk melaksanakan pekerjaan rumah sebagai tanggung jawab mereka. Di dalam jenis pembagian kerja yang kedua istri tetap menjadi penanggungjawab utama tugas

\footnotetext{
${ }^{31}$ Nurmalinar Harahap, Masrianun Siregar, Ratna Dewi Pakpahan, Nurhalinda Siregar, dan Nurhawani Zebua, wawancara hari Sabtu 17 September 2016 Pukul 11.10 WIB.
} 


\section{Jurnal Kajian Gender dan Anak}

Vol. 02 No. 2 Desember 2018

Pusat Studi Gender dan Anak

IAIN Padangsidimpuan

rumah tangga, namun karena suami sadar akan tanggung jawabnya, maka pembagian kerja di dalam rumah tangga sudah adil.

Pada jenis keluarga yang pertama belum terjadi pembagian kerja secara penuh antara suami dan istri karena pelaksanaan pekerjaan rumah tangga yang dilakukan oleh suami hanya sekadar membantu istri. Jadi, mereka beranggapan bahwa ketika perempuan bekerja di luar rumah, tanggung jawab atas pekerjaan rumah tetap menjadi tanggungan bagi istri dan sebagai suami mereka hanya membantu semampu mereka. ${ }^{32}$

Sementara keluarga yang masih terikat dengan adat batak (budaya patriarkhi), pekerjaan domestik hanya dikerjakan oleh istri seperti mengurus rumah, merawat anak, memasak, mencuci dan urusan rumah tangga lainnya. Sementara tugas suami mengantar anak ke sekolah, membayar listrik, membersihkan kenderaan dan memperbaiki peralatan rumah yang rusak baik yang masih bisa ditangani sendiri maupun yang membutuhkan bantuan orang lain. Menurut pengamatan peneliti keluarga yang masih terikat dengan sistem patriarkhi ini, keluarga yang istrinya tidak bekerja, walaupun ada yang istrinya bekerja namun tugas rumah tangga tidak sepenuhnya ada pada tanggung jawab istri. Berbeda dengan wanita yang tidak bekerja, mereka mengerjakan seluruh beban/pekerjaan rumah tangga tanpa ada bantuan dari suami mereka. ${ }^{33}$ '

\section{E. PEMBAHASAN HASIL PENELITIAN}

Pada masyarakat Batak yang menganut sistem kekerabatan patrilineal, budaya patriarkinya masih sangat kental. Pada sistem kekerabatan seperti ini nilai anak laki-laki lebih tinggi dari pada anak perempuan. Anak laki-laki yang karena kedudukannya selaku penerus

${ }^{32}$ Amri Siregar, Ridwan Rangkuti, Maruli Pane, wawancara hari Minggu 18 September 2016 Pukul 10.15 WIB.

${ }^{33}$ Saidah Pane,Siti Raya Lubis, Ratnawati, Nurainun, dan Masrani, wawancara hari Minggu 18 September 2016 Pukul 9.00 WIB 


\section{Keharmonisan Keluarga Wanita Karir .... \\ Asnah \\ asnah@iain-padangsidimpuan.ac.id}

keturunan dalam keluarga, maka mereka akan merasa lebih superior dan berkuasa. Sementara perempuan ada pada posisi inferior.

Demikian pula halnya pada masyarakat Padangmatinggi Lestari, walaupun mereka sudah lebih terbuka menerima persamaan gender ini, namun dalam persoalan peran laki-laki dan perempuan dalam mengerjakan tugas rumah tangga, masih ada pemahaman bahwa tugas rumah tangga adalah pekerjaan perempuan. Masyarakat masih menganggap tabu apabila terlihat ada laki-laki yang terlihat menjemur pakaian atau melaksanakan tugas rumah tangga lainnya.

Masyarakat secara tidak langsung terus saja mengukuhkan bahwa wanita yang berkarier juga harus memiliki kapasitas dalam pengelolaan rumah tangga yang baik. Wanita dibebani banyak sekali pekerjaan seumur hidupnya dan hal ini juga dipahami oleh wanita karier di kelurahan Padangmatinggi Lestari, mereka tidak menganggap bahwa peran itu suatu beban baginya. Sehingga pemberdayaan mereka dari kelima aspek (kesejahteraan, akses, kesadaran kritis, partisipasi dan kontrol/kuasa) tidak mempengaruhi sikap dan perilaku mereka untuk menjaga keharmonisan keluarga. Hal ini dikarenakan mereka tidak banyak menuntut kesetaraan gender, yang mereka pahami bahwa keinginan mereka bekerja hanya meningkatkan kesejahteraan keluarga dan aktualisasi diri. Selain itu dukungan dari keluarga juga membuat wanita karier ini merasakan ketenangan dan kenyamanan dalam menjalankan tugas-tugasnya.

Apabila dianalisis menggunakan perspektif sosiologi dan gender, dalam keluarga wanita karier di kelurahan Padangmatinggi Lestari masih terjadi bias gender dalam pemahaman suami istri mengenai hak dan kewajiban mereka di dalam keluarga. Masih terdapat bias gender di dalam kedudukan keluarga, seperti wanita berkedudukan di bawah suami serta wanita yang bertanggungjawab terhadap ranah domestik keluarga. Feminisme sosialis berupaya untuk memerangi konstruksi visi dan 


\section{Jurnal Kajian Gender dan Anak}

Vol. 02 No. 2 Desember 2018

Pusat Studi Gender dan Anak

IAIN Padangsidimpuan

ideologi masyarakat serta struktur yang tidak adil yang dibangun atas bias gender. ${ }^{34}$ Paham tersebut belum bisa secara sempurna diterima oleh masyarakat di kelurahan Padangmatinggi Lestari karena masih adanya hierarki di dalam keluarga.

\section{F. KESIMPULAN}

Berdasarkan temuan-temuan dan pembahasan hasil sebelumnya, maka dapat disimpulkan:

1. Pemberdayaan wanita karier di kelurahan Padangmatinggi Lestari masih pada aspek kesejahteraan dan partisipasi. Sementara aspek akses, kesadaran kritis dan kontrol/kuasa belum sepenuhnya diberdayakan.

2. Faktor yang mendorong wanita di kelurahan Padangmatinggi Lestari bekerja umumnya faktor ekonomi, yaitu untuk mendukung perekonomian keluarga. Hanya sebahagian kecil yang bekerja karena kesadarannya untuk berpartisipasi dalam sektor publik. Hal ini sejalan dengan rendahnya kesadaran kritis tentang kesamaan genser.

3. Kondisi keluarga wanita karier di kelurahan Padangmatinggi dapat dikatakan harmonis. Karena para wanita karier tetap menjalankan tugasnya sebagai ibu rumah tangga dengan baik, namun masih terdapat bias gender dalam pembagian tugas di dalam rumah tangga.

${ }^{34}$ Huzaimah Tahido Yanggo, "Pandangan Islam tentang Gender", dalam Mansour Fakih dkk (ed), Membincang Feminisme Diskursus Gender Perspektif Islam (Surabaya: Risalah Gusti, 2012), hlm. 27. 


\section{Keharmonisan Keluarga Wanita Karir .... \\ Asnah \\ asnah@iain-padangsidimpuan.ac.id}

\section{DAFTAR PUSTAKA}

Abdullah A. Jawas. Dilema Wanita Karir: Menuju Keluarga Sakinah. Yogyakarta: ABABIL, 1996.

Brunetta R. Wolfman. Peran Kaum Wanita. Yogyakarta: Kanisius, 2008.

C. Utami Munandar, S.“Wanita Karier: Tantangan dan Peluang” dalam Atho Mudzar (ed), dkk, Wanita dalam Masyarakat Indonesia: Akses, Pemberdayaan dan Kesempatan. Yogyakarta: Sunan Kalijaga Press, 2001.

Fadilah. Pengantar Kajian Gender. Jakarta: PSW UIN IIESP, 2003.

Harun, Fatmawati. Faktor-faktor yang Mempengaruhi Perempuan Bekerja dan Kesejahteraan Keluarga. Yogyakarta: Gadjah Mada University Press, 2010.

http://tarwhiteangel.blogspot.com/2009/11/sekretaris-sebagai-wanitakarier.html.

Huzaimah Tahido Yanggo. "Pandangan Islam tentang Gender", dalam Mansour Fakih dkk (ed), Membincang Feminisme Diskursus Gender Perspektif Islam. Surabaya: Risalah Gusti, 1996.

Irwan Abdullah. Problematika Hukum Islam Kontemporer. Jakarta: Pustaka Firdaus, 2002.

Jane Carry Peck. Wanita dalam Keluarga. Yogyakarta: Kartisius, 2002.

La Rose. Dunia Wanita. Jakarta: Pustaka, 2005.

M. Faqih. Analisis Gender dan Transformasi Sosial. Yogyakarta: Pustaka Pelajar, 1996.

Mahfudli Sahli. Menuju Rumah Tangga Harmonis. Pekalongan: Bahagian Batang, 2003.

Moekijat. Perencanaan dan Pengembangan Karir Pegawai. Jakarta: Remaja Karya, 2006.

Munandar Sulaiman. Ilmu Sosial Dasar. Bandung: Risco, 2006. 


\section{Jurnal Kajian Gender dan Anak}

Vol. 02 No. 2 Desember 2018

Pusat Studi Gender dan Anak

IAIN Padangsidimpuan

Nasruddin Umar. Kodrat Perempuan dalam Islam. Jakarta: Fikahati Aneska, 2000.

Omas Ihromi. "Wanita Bekerja dan Masalah-masalahnya", dalam Toety Hearty Nurdhi dan Aida Fitalaya S. Hubeis (ed), dinamika Wanita Indonesia Seri 01: Multidimensional. Jakarta: Pusat Studi Pengembangan Sumber Daya Wanita, 1990.

Purwandari. Perempuan dan Pemberdayaan. Jakarta: Oborr, 2007.

Rahayu Surtiat. Perempuan Indonesia dalam Masyarakat yang Tengah Berubah. Jakarta: PKSW UI, 2000.

Ray Sitoresmin Prabuningrat. Tenaga Kerja Wanita Indonesia. Yogyakarta: Tiara Wacana 2003.

Sri Wulandari. "Pola Komunikasi Wanita Karier dalam Mempertahankan Keharmonisan Keluarga di Kelurahan Bahu" dalam Jurnal Acta Diurna, Vol. 2 No. 2 Tahun 2013.

T.O. Ihromi, (ed.). Bunga Rampai Sosiologi Keluarga. Jakarta: Yayasan Obor Indonesia, 1999.

Tim Penyusun Kamus Pusat Bahasa. Kamus Besar Bahasa Indonesia. Jakarta: Balai Pustaka, 2005.

Viranda Rinantri. "Persepsi Pengembangan Karir Ditinjau Dari Konflik Peran Ganda dan Dukungan Sosial Pada Karyawan Wanita di PT. Gula Putih Mataram Lampung Tengah", dalam Humaniora, Vol. 19 No. 2 Tahun 2016.

Widaningrum. Metode Moser dan Aplikasinya. Yogyakarta: Pusat Studi Wanita UGM, 1998.

William J. Goode. Sosiologi Keluarga. Jakarta: Bumi Aksara, 2001. www.fatihsyuhud.com 